\title{
Influence of growth regulators on the development, quality, and physiological state of in vitro-propagated Lamprocapnos spectabilis (L.) Fukuhara
}

\author{
Dariusz Kulus ${ }^{1}$ \\ Received: 29 July 2019 / Accepted: 21 January 2020 / Published online: 4 March 2020 / Editor: Jayasankar Subramanian \\ (C) The Author(s) 2020
}

\begin{abstract}
There is little information on the in vitro tissue culture systems in Lamprocapnos spectabilis (bleeding heart). The aim of this study was to analyze the influence of plant growth regulators (PGRs) on the development, quality, and physiological state of in vitro-grown bleeding heart "Gold Heart" and "White Gold". Single-node explants were inoculated on the modified MS medium (Murashige and Skoog in Physiol Plant 15:473-497, 1962), fortified with different auxins, which included indole-3acetic acid (IAA), 1-naphthaleneacetic acid (NAA), and picloram (PIC), along with cytokinins, which included 6-benzyladenine (BA), kinetin (KIN), and thidiazuron (TDZ) at various concentrations. The morphogenetic response of the explants was cultivarspecific. KIN was preferable for the proliferation and development of shoots in "Gold Heart." However, none of the auxins or cytokinins improved the development of "White Gold" explants, compared with the PGR-free control medium. NAA was the most effective for stimulating rhizogenesis in both cultivars, although IAA resulted in the regeneration of the longest roots. TDZ, NAA, and PIC suppressed the development of shoots in both cultivars tested and stimulated abundant callus formation. Indirect regeneration of somatic embryos occurred on the NAA- and PIC-fortified media. In particular, the latter media stimulated regeneration of the highest number of somatic embryos per nodal segment. Composition of the culture medium also affected the levels of primary and secondary metabolites in shoots and callus of L. spectabilis. IAA (at $1.0 \mathrm{mg} \mathrm{L}^{-1}$ ) stimulated the synthesis of chlorophyll $a$ and carotenoids in the "Gold Heart," while BA and KIN (at 0.5 mg L" ) had a negative impact on the concentration of chlorophyll $b$ in the shoots of this cultivar. None of the PGRs increased the level of the pigments in the shoots of bleeding heart "White Gold." The concentration of chlorophylls and carotenoids in the callus of both cultivars tested was significantly lower compared with the shoots; however, callus was abundant in flavanols.
\end{abstract}

Keywords Bleeding heart $\cdot$ Callogenesis $\cdot$ Caulogenesis $\cdot$ Rhizogenesis $\cdot$ Somatic embryo

\section{Introduction}

Lamprocapnos spectabilis (L.) Fukuhara or bleeding heart is a popular herbaceous perennial, native to northeast Asia (Roberts et al. 1995). It is a temperate, long-day shade plant species (Hodges 2012). Based on DNA sequencing and pollen and seed coat anatomy observations, the species was reclassified in 1997 in the small botanical family -

Dariusz Kulus

dkulus@gmail.com

1 Faculty of Agriculture and Biotechnology, Laboratory of Ornamental Plants and Vegetable Crops, UTP University of Science and Technology in Bydgoszcz, 6 Bernardyńska St, 85-029 Bydgoszcz, Poland
Fumariaceae (previously Papaveraceae) (Lidén et al. 1997). Bleeding heart has arching stems (racemes), with more than ten pendent red, pink, or white cordate flowers in two planes of symmetry. The flowers have a high ornamental value on the floristic market and in gardening (Hodges 2012). At the base of each outer flower petal is a spur, which holds nectar from the glands. The nectar is abundant in nitrogenous secondary metabolites, such as berberine, cheilantifoline, coptisine, scoulerine, and other isoquinolines, which are valuable for medical use (Iwasa and Kim 1997; McNulty et al. 2007).

Lamprocapnos spectabilis is propagated mainly vegetatively by cuttings (Hodges 2012). The economy of this method, however, is reduced by the limited number of offspring produced. Moreover, it is affected by environmental conditions, such as temperature, humidity, and sunlight during the relatively long horticultural timeframe. It is also time- 
consuming to maintain and requires significant expenditure. In vitro reproduction of plants overcomes those problems and has become an important segment of the economy (Kulus 2015). Due to the enormous potential in horticulture, pharmacology, and cosmetology, the study of bleeding heart in the laboratory is justified and needed.

In vitro tissue culture is currently the most basic tool used in both basic and applied plant studies and for commercial purposes. It is based on totipotency, which is the unique ability of plants to recover an entire organism from just a single nonzygotic cell (or even individual protoplasts). The in vitro technologies are applied to an increasing number of plant species; however, information on tissue culture in bleeding heart is limited to the induction of somatic embryogenesis by 2,4dichlorophenoxyacetic acid (2,4-D) (Lee and Lee 2003; Lee et al. 2004) and should be investigated.

The efficiency of a tissue culture system depends on numerous elements that require careful consideration. They can be divided into two main groups, which include (1) physical factors, such as light and temperature conditions in the growth room or explant parameters, and (2) chemical factors, such as the type and concentration of plant growth regulators (PGRs), osmotic and solidifying agents, and $\mathrm{pH}$ of the culture medium. In the study by Miler et al. (2019), optimal light parameters were set for in vitro cultivation of $L$. spectabilis using fluorescent tubes and wide-spectrum light emitting diodes (LEDs). The study showed that fluorescent tubes were superior to LEDs in terms of propagation ratio, shoot length, and leaf number. However, the role of PGRs in the development of bleeding heart explants, or any other Fumariaceae species cultured in vitro, is still not well understood.

The effects of natural and synthetic plant growth regulators are rarely specific in their influence on growth and development in vitro and can vary greatly with culture conditions or the genotype (Gaspar et al. 1996). Apart from regulating cell growth and differentiation, PGRs are among the most significant factors that affect the metabolite production in plants. In vitro-grown plant material provides the advantage of a continuous and reliable source of valuable pharmaceuticals, because yield is normally low in field-grown plants and influenced by variations in environmental conditions (Mohammad et al. 2014). Considering the medicinal potential of the species, it would be beneficial to know how various PGRs affect the levels of primary and secondary metabolites in in vitro-cultivated bleeding heart, as no such information is currently available.

The aim of this study was to provide for the first time some basic knowledge of the influence of various common and affordable plant growth regulators (auxins and cytokinins), on the development, quality, and physiological state of two of the most popular cultivars of Lamprocapnos spectabilis ("Gold Heart" and "White Gold"), cultivated in vitro.

\section{Materials and Methods}

Culture medium and physical conditions in the growth room The modified Murashige and Skoog (MS) medium (Murashige and Skoog 1962), with increased by half concentration of calcium II chloride $\left(\mathrm{CaCl}_{2} \cdot 6 \mathrm{H}_{2} \mathrm{O}\right)$ and iron sulfate $\left(\mathrm{FeSO}_{4}\right)$, supplemented with $3 \%(w / v)$ sucrose, and solidified with $0.8 \%$ $(w / v)$ agar (Biocorp, Warsaw, Poland), was used in the experiment. The $\mathrm{pH}$ was adjusted to 5.8 (with $0.1-\mathrm{M} \mathrm{HCl}$ and $0.1-\mathrm{M}$ $\mathrm{NaOH}$; Chempur, Piekary Ślaskie, Poland), after adding all media components (Chemia, Bydgoszcz, Poland), prior to autoclaving at $105 \mathrm{kPa}$ and $121^{\circ} \mathrm{C}$ for $20 \mathrm{~min}$ (autoclave SMS ASVE, Góra Kalwaria, Poland). The medium $(40 \mathrm{~mL})$ was poured into $350-\mathrm{mL}$ glass jars and sealed with plastic caps (produced by a local manufacturer).

The cultures were kept in the growth room at $24{ }^{\circ} \mathrm{C} \pm 1^{\circ} \mathrm{C}$, under 16-h photoperiod conditions and photosynthetic photon flux density of approximately $33.8 \mu \mathrm{mol} \mathrm{m}{ }^{-2} \cdot \mathrm{s}^{-1}$, which was provided by standard cool daylight TLD 54/36 W fluorescent tubes, with a color temperature of $6200 \mathrm{~K}$ (Koninklijke Philips Electronics N.V., Eindhoven, Netherlands).

Biological material and multiplication of plants In vitro-derived plantlets of Lamprocapnos spectabilis (L.) Fukuhara "Gold Heart" and "White Gold" were used as the source of explants. Axenic cultures of the two cultivars were obtained from the international commercial plant tissue culture laboratory Vitroflora in Łochowo, Poland.

Donor plants, approximately 10 to $12 \mathrm{~cm}$ long, were cloned using the single-node method in the modified MS medium (described earlier), devoid of plant growth regulators, to produce the appropriate amount of plant material. For this purpose, shoots were cut into nodal segments and subcultured on a fresh medium with six explants per jar, every $16 \mathrm{wk}$. for 8 mo. One inoculated explant produced one shoot, from which approximately eight secondary explants could be dissected.

Effect of various growth regulators on the morphogenetic response of explants The 16-wk-old shoots were cut into single-node segments, 5 to $10 \mathrm{~mm}$ long (Fig. 1a), without leaves and inoculated vertically in the modified MS medium. Various types of auxins, which included indole-3-acetic acid (IAA), 1-naphthaleneacetic acid (NAA), picloram (PIC), and cytokinins, which included 6-benzyladenine (BA), kinetin (KIN), and thidiazuron (TDZ), were added into the medium at the concentration of 0.5 or $1.0 \mathrm{mg} \mathrm{L}^{-1}$. All PGRs were provided by Sigma-Aldrich ${ }^{\circledR}$, St. Louis, MO. A PGR-free control was also included. The in vitro cultures were cultivated for $8 \mathrm{wk}$.

Biometrical analysis of plants After a single propagation cycle, the number, length [mm], and fresh weight [mg] of the shoots were measured. The rooting efficiency [\%], number, and 

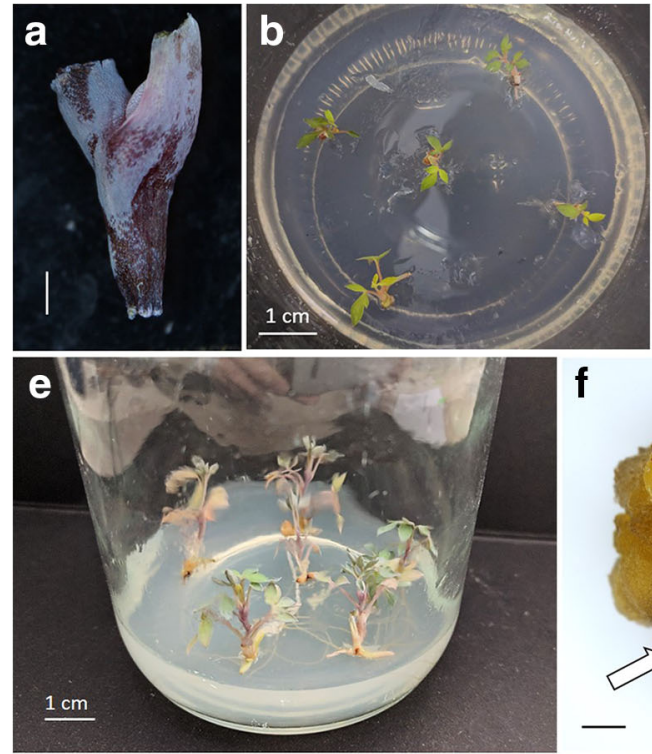

h
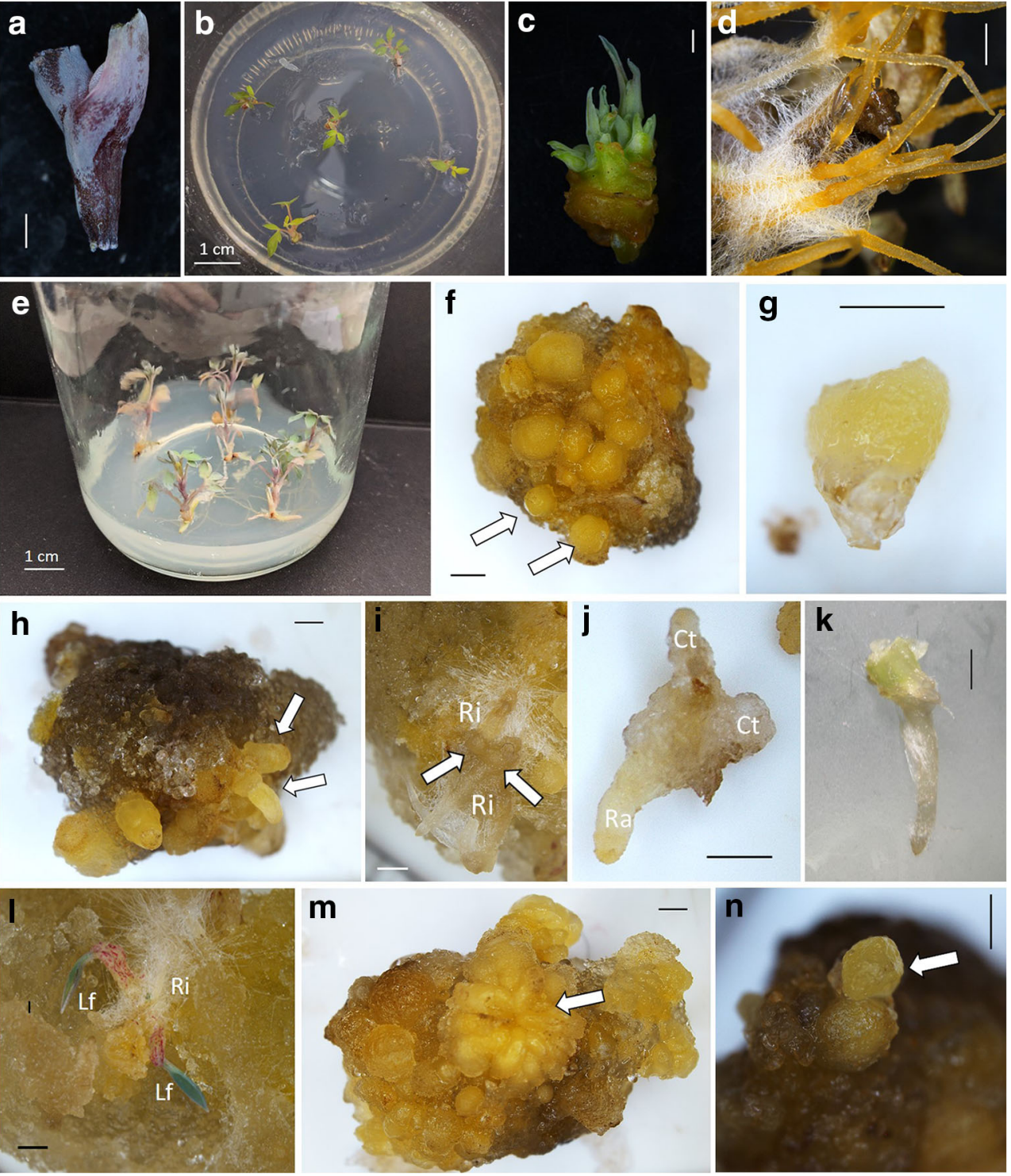

Figure 1. In vitro development of Lamprocapnos spectabilis (L.) Fukuhara "Gold Heart" (GH) and "White Gold" (WG), on the modified MS medium (Murashige and Skoog 1962), fortified with various plant growth regulators. $a$ Nodal segments used in the experiment; $b$ early development of nodal explants (GH, MS + 1.0-mg L $\left.\mathrm{L}^{-1} \mathrm{KIN}\right) ; c$ proliferation of axillary shoots $\left(\mathrm{GH}, \mathrm{MS}+0.5-\mathrm{mg} \mathrm{L}^{-1} \mathrm{KIN}\right) ; d$ regeneration of roots with root hair (WG, MS + 0.5-mg L ${ }^{-1} \mathrm{NAA}$ ); $e$ well-developed microshoots (GH, MS + 1.0-mg L $\left.\mathrm{L}^{-1} \mathrm{IAA}\right)$; and $f-n$ indirect development of somatic embryos (indicated with arrows) (f globular stage (WG, MS + 1.0 - $\mathrm{mg} \mathrm{L}^{-1}$ PIC); $g$ heart stage (WG, MS + 0.5-mg L ${ }^{-1}$ PIC); $h$ torpedo stage (GH, $\left.\mathrm{MS}+0.5-\mathrm{mg} \mathrm{L}^{-1} \mathrm{PIC}\right) ; i$ somatic embryos regenerating roots (Ri) (GH, MS + 1.0-mg L $\left.\mathrm{L}^{-1} \mathrm{NAA}\right) ; j$ germinated embryo with cotyledons $(\mathrm{Ct})$ and radicle $(\mathrm{Ra})\left(\mathrm{GH}, \mathrm{MS}+1.0-\mathrm{mg} \mathrm{L}^{-1} \mathrm{PIC}\right) ; k$ well-developed embryo (GH, MS + $\left.1.0 \mathrm{mg} \mathrm{L}^{-1} \mathrm{PIC}\right)$; $l$ conversion into complete plantlet with roots (Ri) and leaves (Lf) $\left(\mathrm{GH}, \mathrm{MS}+1.0-\mathrm{mg} \mathrm{L}^{-1} \mathrm{PIC}\right) ; m$ multiembryo (GH, MS + 1.0-mg L $\left.{ }^{-1} \mathrm{PIC}\right)$; and $n$ secondary embryogenesis (WG, MS + 1.0-mg L ${ }^{-1}$ PIC)). Photos taken after $3 \mathrm{wk} .(b-c)$ and $8 \mathrm{wk}$. $(d-n)$ in culture. Bar $=1 \mathrm{~mm}$, unless otherwise stated. IAA indole-3-acetic acid; KIN kinetin; NAA 1-naphthaleneacetic acid; PIC picloram.

Biochemical array Spectrophotometric analysis of in vitrogrown plant pigments, extracted from at least five 100-mg fresh shoot or callus samples (if no shoots were available), from every experimental combination was performed. The extraction of chlorophylls, carotenoids, and flavanols was performed with the method described by Lichtenthaler (1987), with $100 \%$ acetone (Chemia, Bydgoszcz, Poland). The spectrophotometric analysis of extracts was performed using a spectrophotometer (SmartSpec Plus ${ }^{\mathrm{TM}}$, Bio-Rad croscope (Nikon, Tokyo, Japan). 
Laboratories, Hercules, CA, and UV-VIS 1601-PC SHIMADZU, Kioto, Japan).

Absorption maxima were defined for pigment-specific wavelengths $\left(\lambda_{\max }\right)$ of $330 \mathrm{~nm}$ for flavanols, at $470 \mathrm{~nm}$ for carotenoids, and at 645 and $662 \mathrm{~nm}$ for chlorophyll $a$ and $b$, respectively. The level of chlorophylls and carotenoids per $g$ of fresh matter was calculated with the algebraic method following Lichtenthaler and Buschmann (2001).

Statistical analysis The single-factor experiment was repeated four times for two cultivars, independently. One jar with five explants was considered as a single repetition.

For the data expressed as a percentage, the Freeman-Tukey transformation was used. After the appropriate normality transformation, the results (completely randomized design) were statistically analyzed with one-way ANOVA, and the comparisons of means were made with HSD Tukey's multiple comparison test $(P \leq 0.05)$ using Statistica 12.0 and ANALWAR-5.2-FR tools. Tables with results provide real numerical data, while alphabet letters point to homogenous groups, which follow the statistical calculations based on transformed data.

\section{Results}

The development of callus on the NAA-, TDZ-, and PICsupplemented media began in the second week of culture. For the other PGRs, callus formation started in the third or fourth week, followed by the control (only in "Gold Heart"). The development of shoots and roots (if present), on the PGRsupplemented media, was quite simultaneous and evident in the third week of culture (Fig. 1b). For the PGR-free control, roots started to regenerate only after shoots were developed with at least a few leaves.

Development of shoots and callogenesis efficiency The highest number of bleeding heart "Gold Heart" shoots produced by a single explant (3.3), with the greatest number of leaves (22.9), was found on the medium fortified with $0.5 \mathrm{mg} \mathrm{L}^{-1}$ KIN (Table 1; Fig. 1c). Shoots produced on this medium were also longer ( $30 \mathrm{~mm}$ per explant), compared with the control $(13.4 \mathrm{~mm})$. The greatest fresh weight of shoots per explant (159.0 to $324.8 \mathrm{mg}$ ) was reported with $0.5-\mathrm{mg} \mathrm{L}^{-1}$ KIN and 1.0-mg L ${ }^{-1}$ BA (Table 1).

With the "White Gold" cultivar, none of the auxins or cytokinins added into the medium had a positive effect on the proliferation of shoots, their length, fresh weight, or number of leaves compared with the PGR-free control (Table 1).

TDZ, NAA, and PIC suppressed the formation of shoots in both cultivars tested and stimulated abundant callus formation in all of the explants (Table 1). Callus was also formed at the base of shoots in the presence of BA (83.3-100\% explants) and KIN (37.5 to $81.2 \%$ ), although in much lower levels.
Rooting efficiency Application of PGRs was necessary to stimulate rhizogenesis, as only $8.3 \%$ of "Gold Heart" explants and $25 \%$ in "White Gold" explants produced roots spontaneously in the control medium (Table 2). Those 25\% "White Gold" shoots, however, regenerated the highest mean number of roots (6.5). The highest rooting efficiency ( 87.5 to $100 \%$ explants) was reported in the medium supplemented with NAA, regardless of the concentration (Fig. 1d). Root formation was less frequent in the presence of IAA (33.3 to $75.0 \%$ explants; Fig. 1e), while the application of cytokinins (except for KIN in "White Gold") and PIC inhibited rooting. Similarly, the explants of both cultivars regenerated the highest number of roots in the NAAsupplemented medium (3.8 to 6.3 per explant); however, the longest roots (12.6 to $20.1 \mathrm{~mm}$ ) were found in the medium with 1.0-mg L $\mathrm{m}^{-1}$ IAA (Table 2).

Callus morphology and somatic embryogenesis The morphology and structure of callus depended on the type of PGR used, although not on the concentration, or the cultivar (Table 3). NAA, especially at higher concentrations, stimulated the formation of callus with the highest diameter (18.8 to $23.8 \mathrm{~mm}$ per explant) and fresh weight (1703.5 to $1816.0 \mathrm{mg}$ ).

Callus that formed on the medium with TDZ had no embryogenic or organogenic potential, regardless of the cultivar (Table 3). It was firm and yellow-green in color. There were also no somatic embryos that regenerated in bleeding heart "White Gold" on the NAA-supplemented medium. Sole application of this auxin did stimulate embryogenesis in the "Gold Heart" cultivar (Table 3). A greater share of embryogenic callus (63.3\% of all inoculated explants) was found if a higher $\left(1.0 \mathrm{mg} \mathrm{L}^{-1}\right)$ concentration of NAA was used, compared with $0.5 \mathrm{mg} \mathrm{L}^{-1}(31.7 \%)$. The highest share of nodal segments that formed embryogenic callus $(66.7-100 \%)$ and the highest mean number of somatic embryos for each inoculated explant (2.9 to 4.1) were reported in the presence of PIC in both cultivars tested, regardless of the concentration.

All somatic embryos had an indirect origin. They were bipolar (starting from the heart stage) and had a typical shape and glossy appearance (Fig. $1 f-n$ ). The embryos could be easily isolated from the explant; they had no vascular connections with the mother tissue. Typical developmental stages of somatic embryos, which included globular (Fig. $1 f$ ), heart (Fig. $1 g$ ), and torpedo (Fig. 1h), were observed. Some of the embryos already formed radicles, roots and cotyledons, or leaves (Fig. $1 i-l$ ). Multiembryos (several somatic embryos connected in an inseparable clump) (Fig. $1 \mathrm{~m}$ ) and secondary embryos (embryos regenerating from another somatic embryo) were also found (Fig. 1n). Most of the somatic embryos were yellow, and only some were green.

Globular somatic embryos were usually dominant (40 to $100 \%$ of all embryos), regardless of the medium composition or cultivar (Fig. 2). Modified MS medium with $1.0-\mathrm{mg} \mathrm{L}^{-1}$ NAA stimulated the development of embryos at torpedo stage in bleeding heart "Gold Heart" (60\% of embryos). Only a few 
Table 1 Influence of culture medium composition on the number of Lamprocapnos spectabilis (L.) Fukuhara shoots and leaves formed from a singlenode explant, shoot length [mm], fresh weight [mg], and the share [\%] of explants forming callus

\begin{tabular}{|c|c|c|c|c|c|c|}
\hline \multicolumn{2}{|c|}{ Medium composition } & \multirow[t]{2}{*}{ No. of shoots } & \multirow[t]{2}{*}{ No. of leaves } & \multirow[t]{2}{*}{ Shoot length [mm] } & \multirow[t]{2}{*}{ Shoot fresh weight $[\mathrm{mg}]$} & \multirow[t]{2}{*}{ Callus $[\%$} \\
\hline PGR $^{*}$ type & $\begin{array}{l}\text { Concentration } \\
{\left[\mathrm{mg} \mathrm{L}^{-1}\right]}\end{array}$ & & & & & \\
\hline & & Gold Heart & & & & \\
\hline Control & - & $1.0 \pm 0.2 \mathrm{cf}^{1}$ & $4.2 \pm 1.0 \mathrm{de}$ & $13.4 \pm 1.9 \mathrm{~b}$ & $107.6 \pm 27.7 \mathrm{~b}$ & $33.3 \mathrm{ab}$ \\
\hline \multirow[t]{2}{*}{$\mathrm{BA}$} & 0.5 & $1.8 \pm 0.3 \mathrm{bc}$ & $12.1 \pm 1.0 \mathrm{bc}$ & $22.6 \pm 1.3 \mathrm{ab}$ & $140.4 \pm 24.0 \mathrm{~b}$ & $83.3 \mathrm{a}$ \\
\hline & 1.0 & $1.5 \pm 0.3 \mathrm{bd}$ & $11.2 \pm 2.0 \mathrm{bc}$ & $25.4 \pm 4.8 \mathrm{ab}$ & $324.8 \pm 92.2 \mathrm{a}$ & $100 \mathrm{a}$ \\
\hline \multirow[t]{2}{*}{ KIN } & 0.5 & $3.3 \pm 0.5 \mathrm{a}$ & $22.9 \pm 2.2 \mathrm{a}$ & $30.0 \pm 3.5 \mathrm{a}$ & $159.0 \pm 36.4 \mathrm{ab}$ & $58.3 \mathrm{ab}$ \\
\hline & 1.0 & $2.5 \pm 0.5 \mathrm{ab}$ & $14.6 \pm 2.7 \mathrm{~b}$ & $25.9 \pm 2.0 \mathrm{ab}$ & $124.6 \pm 26.7 \mathrm{~b}$ & $75.0 \mathrm{ab}$ \\
\hline \multirow[t]{2}{*}{ TDZ } & 0.5 & $0.4 \pm 0.2 \mathrm{df}$ & $0.4 \pm 0.4 \mathrm{e}$ & n.a. & n.a. & $100 \mathrm{a}$ \\
\hline & 1.0 & $0.5 \pm 0.2 \mathrm{df}$ & $0.4 \pm 0.2 \mathrm{e}$ & n.a. & n.a. & $100 \mathrm{a}$ \\
\hline \multirow[t]{2}{*}{ IAA } & 0.5 & $1.2 \pm 0.1 \mathrm{ce}$ & $6.8 \pm 1.0 \mathrm{~cd}$ & $20.8 \pm 3.0 \mathrm{ab}$ & $81.0 \pm 28.2 \mathrm{~b}$ & $0.0 \mathrm{~b}$ \\
\hline & 1.0 & $1.2 \pm 0.1 \mathrm{ce}$ & $8.2 \pm 0.6 \mathrm{~cd}$ & $24.6 \pm 2.8 \mathrm{ab}$ & $72.8 \pm 13.0 \mathrm{~b}$ & $25.0 \mathrm{ab}$ \\
\hline \multirow[t]{2}{*}{ NAA } & 0.5 & $0.2 \pm 0.1 \mathrm{ef}$ & $0.2 \pm 0.2 \mathrm{e}$ & n.a. & n.a. & $100 \mathrm{a}$ \\
\hline & 1.0 & $0.0 \mathrm{f}$ & $0.0 \mathrm{e}$ & n.a. & n.a. & $100 \mathrm{a}$ \\
\hline \multirow[t]{3}{*}{ PIC } & 0.5 & $0.0 \mathrm{f}$ & $0.0 \mathrm{e}$ & n.a. & n.a. & $100 \mathrm{a}$ \\
\hline & 1.0 & $0.0 \mathrm{f}$ & $0.0 \mathrm{e}$ & n.a. & n.a. & $100 \mathrm{a}$ \\
\hline & & White Gold & & & & \\
\hline Control & - & $1.8 \pm 0.2 \mathrm{a}$ & $8.1 \pm 0.4 \mathrm{ab}$ & $20.6 \pm 1.1 \mathrm{a}$ & $116.2 \pm 13.5 \mathrm{ab}$ & $0.0 \mathrm{c}$ \\
\hline \multirow[t]{2}{*}{$\mathrm{BA}$} & 0.5 & $1.2 \pm 0.1 \mathrm{ab}$ & $8.4 \pm 1.3 \mathrm{ab}$ & $14.9 \pm 0.8 \mathrm{~b}$ & $110.7 \pm 16.3 \mathrm{ab}$ & $100 \mathrm{a}$ \\
\hline & 1.0 & $1.3 \pm 0.2 \mathrm{ab}$ & $7.6 \pm 0.8 \mathrm{ab}$ & $15.3 \pm 1.2 \mathrm{ab}$ & $171.8 \pm 33.4 \mathrm{a}$ & $93.8 \mathrm{a}$ \\
\hline \multirow[t]{2}{*}{ KIN } & 0.5 & $1.4 \pm 0.2 \mathrm{a}$ & $7.4 \pm 0.8 \mathrm{ab}$ & $13.6 \pm 1.2 \mathrm{~b}$ & $71.9 \pm 11.2 \mathrm{~b}$ & $37.5 \mathrm{~b}$ \\
\hline & 1.0 & $1.7 \pm 0.2 \mathrm{a}$ & $10.4 \pm 1.2 \mathrm{a}$ & $20.8 \pm 1.3 \mathrm{a}$ & $136.3 \pm 15.9 \mathrm{ab}$ & $81.2 \mathrm{a}$ \\
\hline \multirow[t]{2}{*}{ TDZ } & 0.5 & $0.7 \pm 0.2 \mathrm{bc}$ & $0.7 \pm 0.2 \mathrm{c}$ & n.a. & n.a. & $100 \mathrm{a}$ \\
\hline & 1.0 & $0.3 \pm 0.2 \mathrm{c}$ & $0.3 \pm 0.2 \mathrm{c}$ & n.a. & n.a. & $100 \mathrm{a}$ \\
\hline \multirow[t]{2}{*}{ IAA } & 0.5 & $1.1 \pm 0.1 \mathrm{ab}$ & $6.4 \pm 0.5 \mathrm{~b}$ & $14.9 \pm 0.8 \mathrm{~b}$ & $55.7 \pm 10.2 \mathrm{~b}$ & $6.2 \mathrm{bc}$ \\
\hline & 1.0 & $1.1 \pm 0.1 \mathrm{ab}$ & $7.6 \pm 0.8 \mathrm{ab}$ & $18.4 \pm 1.9 \mathrm{ab}$ & $96.4 \pm 23.3 \mathrm{ab}$ & $0.0 \mathrm{c}$ \\
\hline \multirow[t]{2}{*}{ NAA } & 0.5 & $0.2 \pm 0.1 \mathrm{c}$ & $0.4 \pm 0.3 \mathrm{c}$ & n.a. & n.a. & $100 \mathrm{a}$ \\
\hline & 1.0 & $0.1 \pm 0.1 \mathrm{c}$ & $0.2 \pm 0.1 \mathrm{c}$ & n.a. & n.a. & $100 \mathrm{a}$ \\
\hline \multirow[t]{2}{*}{ PIC } & 0.5 & $0.0 \mathrm{c}$ & $0.0 \mathrm{c}$ & n.a. & n.a. & $100 \mathrm{a}$ \\
\hline & 1.0 & $0.0 \mathrm{c}$ & $0.0 \mathrm{c}$ & n.a. & n.a. & $100 \mathrm{a}$ \\
\hline
\end{tabular}

\footnotetext{
${ }^{1}$ Means in columns \pm standard errors marked with the same letter do not differ significantly according to the HSD Tukey's test $(P \leq 0.05)$

${ }^{*} B A$ 6-benzyladenine; IAA indole-3-acetic acid; KIN kinetin; n.a. not available due to tiny size of shoots; NAA 1-naphthaleneacetic acid; PGR plant growth regulator; PIC picloram; TDZ thidiazuron
}

somatic embryos at maturity stage (developing root and leaves) were found in "Gold Heart" on the medium containing 1.0$\mathrm{mg} \mathrm{L}^{-1}$ PIC (Fig. 2).

Biochemical array There was a significant influence of the culture medium composition on the level of pigments in L. spectabilis (Table 4). The highest concentrations of chlorophyll $a$ and carotenoids in bleeding heart "Gold Heart" were found in shoots cultured on the medium with $1.0-\mathrm{mg} \mathrm{L}^{-1}$ IAA. BA (regardless of concentration) and $\mathrm{KIN}$ (at $0.5 \mathrm{mg} \mathrm{L}^{-1}$ ) had a negative impact on the level of chlorophyll $b$ in the shoots of this cultivar (Table 4). The chlorophyll $a: b$ ratio in callus usually reached a value $<1.0$ (except for the callus formed on the medium with $1.0-\mathrm{mg} \mathrm{L}^{-1}$ PIC). However, a higher share of chlorophyll $a$ to $b$ could be found in shoots.

For bleeding heart "White Gold," BA (especially at higher concentrations) had a negative impact on the synthesis of chlorophylls and carotenoids in shoots. In addition, KIN at $1.0 \mathrm{mg} \mathrm{L}^{-1}$ decreased by half the level of chlorophyll $b$ in shoots $\left(0.12 \mathrm{mg} \mathrm{g}^{-1}\right.$ fresh weight $)$ compared with the control $\left(0.24 \mathrm{mg} \mathrm{g}^{-1}\right)$. None of the PGRs enhanced the biosynthesis of the analyzed pigments in this cultivar compared with the control (Table 4). Similarly to "Gold Heart," the chlorophyll $a: b$ ratio in "White Gold" was also usually higher in shoots $(>1.0)$ compared with callus $(<1.0)$, except for the calluses formed on the media with 1.0-mg L ${ }^{-1} \mathrm{NAA}$ and $1.0-\mathrm{mg} \mathrm{L}^{-1}$ PIC. 
Table 2. Influence of culture medium composition on the share [\%] of Lamprocapnos spectabilis (L.) Fukuhara explants forming roots, number, and length $[\mathrm{mm}]$ of roots for each inoculated or rooted explant

\begin{tabular}{|c|c|c|c|c|c|c|}
\hline \multicolumn{2}{|c|}{ Medium composition } & \multirow[t]{2}{*}{ Rooting [\%] } & \multirow{2}{*}{$\begin{array}{l}\text { No. of roots per } \\
\text { inoculated explant }\end{array}$} & \multirow{2}{*}{$\begin{array}{l}\text { No. of roots per } \\
\text { rooted explant }\end{array}$} & \multirow{2}{*}{$\begin{array}{l}\text { Root length per } \\
\text { inoculated explant }[\mathrm{mm}]\end{array}$} & \multirow{2}{*}{$\begin{array}{l}\text { Root length per } \\
\text { rooted explant }[\mathrm{mm}]\end{array}$} \\
\hline PGR ${ }^{*}$ type & $\begin{array}{l}\text { Concentration } \\
{\left[\mathrm{mg} \mathrm{L}^{-1}\right]}\end{array}$ & & & & & \\
\hline & & & Gold Heart & & & \\
\hline Control & - & $8.3 \mathrm{~d}$ & $0.2 \pm 0.2 \mathrm{bc}$ & $2.0 \pm 0.0 \mathrm{bc}$ & $0.8 \pm 0.8 \mathrm{bc}$ & $10.0 \pm 0.0 \mathrm{ab}$ \\
\hline \multirow[t]{2}{*}{$\mathrm{BA}$} & 0.5 & $0.0 \mathrm{~d}$ & $0.0 \mathrm{c}$ & - & $0.0 \mathrm{c}$ & - \\
\hline & 1.0 & $0.0 \mathrm{~d}$ & $0.0 \mathrm{c}$ & - & $0.0 \mathrm{c}$ & - \\
\hline \multirow[t]{2}{*}{ KIN } & 0.5 & $0.0 \mathrm{~d}$ & $0.0 \mathrm{c}$ & - & $0.0 \mathrm{c}$ & - \\
\hline & 1.0 & $0.0 \mathrm{~d}$ & $0.0 \mathrm{c}$ & - & $0.0 \mathrm{c}$ & - \\
\hline \multirow[t]{2}{*}{ TDZ } & 0.5 & $0.0 \mathrm{~d}$ & $0.0 \mathrm{c}$ & - & $0.0 \mathrm{c}$ & - \\
\hline & 1.0 & $0.0 \mathrm{~d}$ & $0.0 \mathrm{c}$ & - & $0.0 \mathrm{c}$ & - \\
\hline \multirow[t]{2}{*}{ IAA } & 0.5 & $33.3 \mathrm{c}$ & $1.4 \pm 0.7 \mathrm{~b}$ & $4.3 \pm 0.9 \mathrm{ac}$ & $11.8 \pm 7.5 \mathrm{ab}$ & $35.5 \pm 8.6 \mathrm{a}$ \\
\hline & 1.0 & $75.0 \mathrm{~b}$ & $1.4 \pm 0.4 \mathrm{~b}$ & $1.9 \pm 0.5 \mathrm{c}$ & $20.1 \pm 5.5 \mathrm{a}$ & $26.8 \pm 5.8 \mathrm{a}$ \\
\hline \multirow[t]{2}{*}{ NAA } & 0.5 & $100 \mathrm{a}$ & $5.5 \pm 0.6 \mathrm{a}$ & $5.5 \pm 0.6 \mathrm{ab}$ & $4.9 \pm 0.7 \mathrm{bc}$ & $4.9 \pm 0.7 \mathrm{~b}$ \\
\hline & 1.0 & $100 \mathrm{a}$ & $6.3 \pm 0.6 \mathrm{a}$ & $6.3 \pm 0.6 \mathrm{a}$ & $4.7 \pm 0.5 \mathrm{bc}$ & $4.7 \pm 0.5 \mathrm{~b}$ \\
\hline \multirow[t]{3}{*}{ PIC } & 0.5 & $0.0 \mathrm{~d}$ & $0.0 \mathrm{c}$ & - & $0.0 \mathrm{c}$ & - \\
\hline & 1.0 & $0.0 \mathrm{~d}$ & $0.0 \mathrm{c}$ & - & $0.0 \mathrm{c}$ & - \\
\hline & & & White Gold & & & \\
\hline Control & - & $25.0 \mathrm{~cd}$ & $1.6 \pm 0.8 \mathrm{bc}$ & $6.5 \pm 1.9 \mathrm{a}$ & $3.3 \pm 1.5 \mathrm{ab}$ & $13.0 \pm 0.7 \mathrm{ab}$ \\
\hline \multirow[t]{2}{*}{ BA } & 0.5 & $0.0 \mathrm{~d}$ & $0.0 \mathrm{c}$ & - & $0.0 \mathrm{~b}$ & - \\
\hline & 1.0 & $0.0 \mathrm{~d}$ & $0.0 \mathrm{c}$ & - & $0.0 \mathrm{~b}$ & - \\
\hline \multirow[t]{2}{*}{ KIN } & 0.5 & $62.5 \mathrm{ac}$ & $2.3 \pm 0.7 \mathrm{ac}$ & $3.6 \pm 0.9 \mathrm{ab}$ & $5.9 \pm 1.7 \mathrm{ab}$ & $9.5 \pm 2.0 \mathrm{~b}$ \\
\hline & 1.0 & $43.8 \mathrm{c}$ & $1.6 \pm 0.6 \mathrm{bc}$ & $3.6 \pm 0.8 \mathrm{ab}$ & $7.9 \pm 3.2 \mathrm{ab}$ & $18.0 \pm 5.3 \mathrm{ab}$ \\
\hline \multirow[t]{2}{*}{ TDZ } & 0.5 & $0.0 \mathrm{~d}$ & $0.0 \mathrm{c}$ & - & $0.0 \mathrm{~b}$ & - \\
\hline & 1.0 & $0.0 \mathrm{~d}$ & $0.0 \mathrm{c}$ & - & $0.0 \mathrm{~b}$ & - \\
\hline \multirow[t]{2}{*}{ IAA } & 0.5 & $50.0 \mathrm{bc}$ & $1.6 \pm 1.0 \mathrm{bc}$ & $3.3 \pm 1.8 \mathrm{ab}$ & $8.8 \pm 2.4 \mathrm{ab}$ & $15.6 \pm 2.4 \mathrm{ab}$ \\
\hline & 1.0 & $42.5 \mathrm{bc}$ & $0.9 \pm 0.4 \mathrm{c}$ & $2.1 \pm 0.8 \mathrm{~b}$ & $12.6 \pm 6.0 \mathrm{a}$ & $28.7 \pm 11.3 \mathrm{a}$ \\
\hline \multirow[t]{2}{*}{ NAA } & 0.5 & $100 \mathrm{a}$ & $4.3 \pm 0.6 \mathrm{a}$ & $4.3 \pm 0.6 \mathrm{ab}$ & $8.5 \pm 1.9 \mathrm{ab}$ & $8.5 \pm 1.9 \mathrm{~b}$ \\
\hline & 1.0 & $87.5 \mathrm{ab}$ & $3.8 \pm 0.5 \mathrm{ab}$ & $4.3 \pm 0.5 \mathrm{ab}$ & $3.9 \pm 0.7 \mathrm{ab}$ & $4.5 \pm 0.7 \mathrm{~b}$ \\
\hline \multirow[t]{2}{*}{ PIC } & 0.5 & $0.0 \mathrm{~d}$ & $0.0 \mathrm{c}$ & - & $0.0 \mathrm{~b}$ & - \\
\hline & 1.0 & $0.0 \mathrm{~d}$ & $0.0 \mathrm{c}$ & - & $0.0 \mathrm{~b}$ & - \\
\hline
\end{tabular}

\footnotetext{
${ }^{1}$ Means in columns \pm standard errors marked with the same letter do not differ significantly according to the HSD Tukey's test $(P \leq 0.05)$

* $B A$ 6-benzyladenine; IAA indole-3-acetic acid; KIN kinetin; NAA 1-naphthaleneacetic acid; PGR plant growth regulator; PIC picloram; TDZ thidiazuron
}

The absolute concentration of chlorophyll $a$, chlorophyll $b$, and carotenoids in the callus of both cultivars tested was usually significantly lower compared with the shoots (even 100 to 1000 times, as in the case of carotenoids in callus developed on the NAA-supplemented medium). However, the callus was abundant in flavanols (Fig. 3).

\section{Discussion}

The present research confirmed the applicability of nodal segments in the in vitro studies with bleeding heart, as all of them demonstrated some type of morphogenetic response, such as caulogenesis, rhizogenesis, callogenesis, and/or embryogenesis. The suitability of this explant type was also reported by We et al.
(2015), with Sauropus androgynus (L.) Merr. In their research, nodal segments produced a comparable number of adventitious shoots (7.8) as internodes (5.5) and leaf segments (10.0), in the same culture conditions. In addition, the share of responding explants was similar in most experimental combinations tested ( 83.3 to $96.7 \%$ ). In bleeding heart, the morphogenetic and physiological activity of explants was PGR-dependent.

Activation of axillary meristem and biometrical parameters of shoots In the present study, the effect of various PGRs on the in vitro development and quality of two bleeding heart cultivars was tested. Auxins and cytokinins are among the main regulators of in vitro growth and development. Their effect depends on the biological material, their concentration, conjugation with other compounds, and the interaction with endogenous and artificial 
Table 3. Influence of culture medium composition on the callus morphology, structure, diameter [mm], and fresh weight [mg]; share of Lamprocapnos spectabilis (L.) Fukuhara explants forming embryogenic callus [\%]; and mean and maximal number of somatic embryos regenerated by a single explant

\begin{tabular}{|c|c|c|c|c|c|c|c|}
\hline \multicolumn{2}{|c|}{ Medium composition } & \multirow{2}{*}{$\begin{array}{l}\text { Dominant callus } \\
\text { color andstructure }^{1}\end{array}$} & \multirow[t]{2}{*}{ Callus diameter $[\mathrm{mm}]$} & \multirow{2}{*}{$\begin{array}{l}\text { Callus fresh } \\
\text { weight [mg] }\end{array}$} & \multirow{2}{*}{$\begin{array}{l}\text { Embryogenic callus } \\
{[\%]}\end{array}$} & \multirow{2}{*}{$\begin{array}{l}\text { Mean no. } \\
\text { of embryos }\end{array}$} & \multirow{2}{*}{$\begin{array}{l}\text { Max no. } \\
\text { of embryos }\end{array}$} \\
\hline PGR type ${ }^{*}$ & $\begin{array}{l}\text { Concentration } \\
{\left[\mathrm{mg} \mathrm{L}^{-1}\right]}\end{array}$ & & & & & & \\
\hline & & Gold Heart & & & & & \\
\hline \multirow[t]{2}{*}{ TDZ } & 0.5 & yellow-green & $14.9 \pm 0.7 \mathrm{bc}$ & $497.4 \pm 51.3 \mathrm{c}$ & $0.0 \mathrm{c}$ & $0.0 \mathrm{~b}$ & - \\
\hline & 1.0 & firm & $14.6 \pm 0.9 \mathrm{bc}$ & $474.0 \pm 60.9 \mathrm{c}$ & $0.0 \mathrm{c}$ & $0.0 \mathrm{~b}$ & - \\
\hline \multirow[t]{2}{*}{ NAA } & 0.5 & creamy & $18.4 \pm 1.6 \mathrm{~b}$ & $1007.8 \pm 141.1 \mathrm{~b}$ & $31.7 \mathrm{bc}$ & $1.1 \pm 0.5 \mathrm{~b}$ & 4 \\
\hline & 1.0 & medium-hard & $23.8 \pm 1.8 \mathrm{a}$ & $1816.0 \pm 219.1 \mathrm{a}$ & $63.3 \mathrm{ab}$ & $2.2 \pm 0.6 \mathrm{ab}$ & 7 \\
\hline \multirow[t]{3}{*}{ PIC } & 0.5 & yellow-gray & $13.0 \pm 0.9 \mathrm{c}$ & $470.3 \pm 79.6 \mathrm{c}$ & $100 \mathrm{a}$ & $3.7 \pm 0.9 \mathrm{a}$ & 12 \\
\hline & 1.0 & soft & $10.9 \pm 0.9 \mathrm{c}$ & $207.4 \pm 37.6 \mathrm{c}$ & $100 \mathrm{a}$ & $4.1 \pm 0.9 \mathrm{a}$ & 9 \\
\hline & & White Gold & & & & & \\
\hline \multirow[t]{2}{*}{ TDZ } & 0.5 & yellow-green & $12.0 \pm 0.6 \mathrm{~b}$ & $262.6 \pm 24.6 \mathrm{c}$ & $0.0 \mathrm{~b}$ & $0.0 \mathrm{~b}$ & - \\
\hline & 1.0 & firm & $9.4 \pm 0.5 \mathrm{~b}$ & $158.8 \pm 17.6 \mathrm{c}$ & $0.0 \mathrm{~b}$ & $0.0 \mathrm{~b}$ & - \\
\hline \multirow[t]{2}{*}{ NAA } & 0.5 & creamy & $18.8 \pm 1.3 \mathrm{a}$ & $943.9 \pm 180.3 b$ & $0.0 \mathrm{~b}$ & $0.0 \mathrm{~b}$ & - \\
\hline & 1.0 & medium-hard & $22.7 \pm 1.5 \mathrm{a}$ & $1703.5 \pm 285.6 \mathrm{a}$ & $0.0 \mathrm{~b}$ & $0.0 \mathrm{~b}$ & - \\
\hline \multirow[t]{2}{*}{ PIC } & 0.5 & yellow-gray & $11.1 \pm 0.7 \mathrm{~b}$ & $298.8 \pm 32.7 \mathrm{bc}$ & $66.7 \mathrm{a}$ & $2.9 \pm 1.0 \mathrm{a}$ & 10 \\
\hline & 1.0 & soft & $8.1 \pm 0.4 b$ & $142.1 \pm 16.9 \mathrm{c}$ & $93.8 \mathrm{a}$ & $3.2 \pm 0.6 \mathrm{a}$ & 11 \\
\hline
\end{tabular}

${ }^{1}$ Means in columns \pm standard errors marked with the same letter do not differ significantly according to the HSD Tukey's test $(P \leq 0.05)$

* $B A$ 6-benzyladenine; IAA indole-3-acetic acid; KIN kinetin; NAA 1-naphthaleneacetic acid; PGR plant growth regulator; PIC picloram; TDZ thidiazuron

growth regulators or other physical factors in the growth room. For example, in the study by Pahnekolayi et al. (2015), the cytokinin BA alone was the most effective for stimulating shoot proliferation in Rosa canina L. nodal segments, compared with several other combinations of BA, gibberellic acid $\left(\mathrm{GA}_{3}\right)$, and NAA. NAA auxin (1.0 mg L $\left.{ }^{-1}\right)$ was preferable for stimulation of adventitious shoot regeneration from leaf explants of Ajania pacifica "Silver and Gold," compared with BA or TDZ (Tymoszuk and Antkowiak 2018). For the encapsulated nodal segments of chrysanthemum, the effect of various cytokinins (CKs) was cultivar-specific (Kulus and Zalewska 2014). In the present study, addition of $0.5-\mathrm{mg} \mathrm{L}^{-1} \mathrm{KIN}$ to the culture medium was optimal for bleeding heart "Gold Heart" shoot proliferation, shoot length, and number of leaves. However, a higher fresh weight (FW) of shoots was reported when $1.0-\mathrm{mg} \mathrm{L}^{-1}$ BA was applied. FW is an important parameter to describe the leaf biomass and area. In addition, FW reflects the physiological functions of leaves associated with photosynthesis and respiration (Huang et al. 2019). The present study confirmed that cytokinins are more effective than auxins for stimulating the activation of lateral buds and the formation of multiple axillary shoots of high quality in L. spectabilis "Gold Heart." It should be emphasized that none of the PGRs tested improved the biometric parameters of shoots of bleeding heart "White Gold." This cultivar may have other requirements for optimal growth in vitro.

Rhizogenesis Auxins stimulate the expression of numerous genes in the plant. Disturbance of the homeostasis can have great effects on root growth and development (Overvoorde et al. 2010). The present study confirmed that similar to other plant species (Simon and Petrášek 2011), bleeding heart rooting is also induced by IAA and NAA. Spontaneous rooting on a PGR-free
Figure 2. Influence of culture medium composition on the maturation of somatic embryos in Lamprocapnos spectabilis (L.) Fukuhara "Gold Heart" $(a)$ and "White Gold" (b) after 8 wk. in culture. NAA 1-naphthaleneacetic acid; PIC picloram; PGRs plant growth regulators.
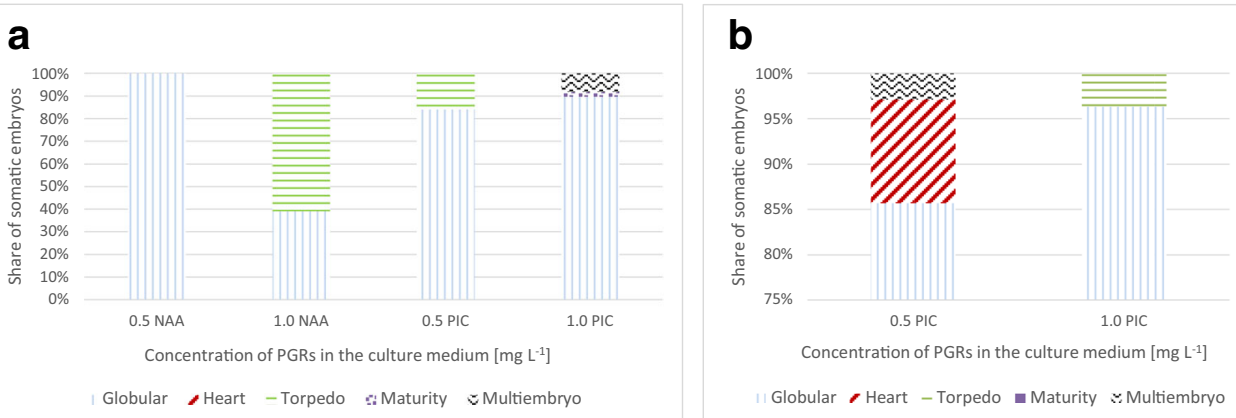
Table 4. Influence of culture medium composition on the concentration of chlorophyll $a$, chlorophyll $b$, and total carotenoid levels in the recovered shoots and callus ** of Lamprocapnos spectabilis (L.) Fukuhara "Gold Heart" and "White Gold" [mg g ${ }^{-1}$ fresh tissue]

\begin{tabular}{|c|c|c|c|c|c|}
\hline \multicolumn{2}{|c|}{ Medium composition } & \multirow{2}{*}{$\begin{array}{l}\text { Chlorophyll } a \\
{\left[\mathrm{mg} \mathrm{g}^{-1}\right]}\end{array}$} & \multirow{2}{*}{$\begin{array}{l}\text { Chlorophyll } b \\
{\left[\mathrm{mg} \mathrm{g}^{-1}\right]}\end{array}$} & \multirow[t]{2}{*}{ Chlorophyll $a: b$ ratio } & \multirow{2}{*}{$\begin{array}{l}\text { Carotenoids } \\
{\left[\mathrm{mg} \mathrm{g}^{-1}\right]}\end{array}$} \\
\hline PGR $^{*}$ type & Concentration $\left[\mathrm{mg} \mathrm{L}^{-1}\right]$ & & & & \\
\hline & & Gold Heart & & & \\
\hline Control & - & $0.42 \pm 0.05 b^{1}$ & $0.26 \pm 0.01 \mathrm{a}$ & $1.59 \pm 0.15 b c$ & $0.11 \pm 0.01 \mathrm{bc}$ \\
\hline \multirow[t]{2}{*}{$\mathrm{BA}$} & 0.5 & $0.39 \pm 0.03 \mathrm{bc}$ & $0.16 \pm 0.01 \mathrm{bc}$ & $2.51 \pm 0.14 \mathrm{ab}$ & $0.10 \pm 0.01 \mathrm{bc}$ \\
\hline & 1.0 & $0.30 \pm 0.03 \mathrm{c}$ & $0.09 \pm 0.01 \mathrm{~cd}$ & $3.55 \pm 0.52 \mathrm{a}$ & $0.09 \pm 0.01 \mathrm{c}$ \\
\hline \multirow[t]{2}{*}{ KIN } & 0.5 & $0.41 \pm 0.02 \mathrm{~b}$ & $0.15 \pm 0.01 \mathrm{bc}$ & $2.80 \pm 0.15 \mathrm{ab}$ & $0.10 \pm 0.001 \mathrm{bc}$ \\
\hline & 1.0 & $0.47 \pm 0.03 \mathrm{~b}$ & $0.25 \pm 0.02 \mathrm{a}$ & $1.89 \pm 0.09 \mathrm{bc}$ & $0.12 \pm 0.01 \mathrm{bc}$ \\
\hline \multirow[t]{2}{*}{ TDZ } & 0.5 & $0.04 \pm 0.00 \mathrm{~d}^{* *}$ & $0.06 \pm 0.01 \mathrm{~d}^{* *}$ & $0.71 \pm 0.11 \mathrm{c}$ & $0.01 \pm 0.001 \mathrm{~d}^{* *}$ \\
\hline & 1.0 & $0.02 \pm 0.01 \mathrm{~d}^{* *}$ & $0.05 \pm 0.01 \mathrm{~d}^{* *}$ & $0.48 \pm 0.07 \mathrm{c}$ & $0.01 \pm 0.001 \mathrm{~d}^{* *}$ \\
\hline \multirow[t]{2}{*}{ IAA } & 0.5 & $0.49 \pm 0.04 \mathrm{ab}$ & $0.20 \pm 0.02 \mathrm{ab}$ & $2.46 \pm 0.05 \mathrm{ab}$ & $0.13 \pm 0.01 \mathrm{ab}$ \\
\hline & 1.0 & $0.62 \pm 0.06 \mathrm{a}$ & $0.26 \pm 0.04 \mathrm{a}$ & $2.49 \pm 0.22 \mathrm{ab}$ & $0.16 \pm 0.01 \mathrm{a}$ \\
\hline \multirow[t]{2}{*}{ NAA } & 0.5 & $0.03 \pm 0.01 \mathrm{~d}^{* *}$ & $0.05 \pm 0.01 \mathrm{~d}^{* *}$ & $0.55 \pm 0.08 \mathrm{c}$ & $0.001 \pm 0.001 \mathrm{~d}^{* *}$ \\
\hline & 1.0 & $0.02 \pm 0.01 \mathrm{~d}^{* *}$ & $0.03 \pm 0.01 \mathrm{~d}^{* *}$ & $0.73 \pm 0.23 \mathrm{c}$ & $0.002 \pm 0.001 \mathrm{~d}^{* * *}$ \\
\hline \multirow[t]{3}{*}{ PIC } & 0.5 & $0.03 \pm 0.01 \mathrm{~d}^{* *}$ & $0.05 \pm 0.01 \mathrm{~d}^{* *}$ & $0.52 \pm 0.04 \mathrm{c}$ & $0.01 \pm 0.001 \mathrm{~d}^{* *}$ \\
\hline & 1.0 & $0.03 \pm 0.02 \mathrm{~d}^{* *}$ & $0.04 \pm 0.03 \mathrm{~d}^{* *}$ & $1.24 \pm 0.49 \mathrm{bc}$ & $0.01 \pm 0.001 \mathrm{~d}^{* *}$ \\
\hline & & White Gold & & & \\
\hline Control & - & $0.41 \pm 0.05 \mathrm{ab}$ & $0.24 \pm 0.05 \mathrm{a}$ & $1.93 \pm 0.17 \mathrm{ac}$ & $0.11 \pm 0.01 \mathrm{ab}$ \\
\hline \multirow[t]{2}{*}{ BA } & 0.5 & $0.26 \pm 0.03 \mathrm{~cd}$ & $0.09 \pm 0.02 \mathrm{bc}$ & $2.98 \pm 0.41 \mathrm{a}$ & $0.09 \pm 0.01 \mathrm{~b}$ \\
\hline & 1.0 & $0.14 \pm 0.03 \mathrm{de}$ & $0.06 \pm 0.01 \mathrm{bc}$ & $2.35 \pm 0.59 \mathrm{ac}$ & $0.05 \pm 0.01 \mathrm{c}$ \\
\hline \multirow[t]{2}{*}{ KIN } & 0.5 & $0.35 \pm 0.04 \mathrm{bc}$ & $0.17 \pm 0.02 \mathrm{ac}$ & $2.10 \pm 0.13 \mathrm{ac}$ & $0.09 \pm 0.01 \mathrm{~b}$ \\
\hline & 1.0 & $0.36 \pm 0.02 b c$ & $0.12 \pm 0.01 \mathrm{bc}$ & $3.12 \pm 0.26 \mathrm{a}$ & $0.10 \pm 0.001 \mathrm{~b}$ \\
\hline \multirow[t]{2}{*}{ TDZ } & 0.5 & $0.06 \pm 0.03 \mathrm{e}^{* *}$ & $0.10 \pm 0.05 \mathrm{bc}^{* *}$ & $0.63 \pm 0.06 \mathrm{bc}$ & $0.01 \pm 0.001 \mathrm{~d}^{* *}$ \\
\hline & 1.0 & $0.04 \pm 0.01 \mathrm{e}^{* *}$ & $0.05 \pm 0.01 \mathrm{bc}^{* *}$ & $0.67 \pm 0.04 \mathrm{bc}$ & $0.01 \pm 0.001 \mathrm{~d}^{* *}$ \\
\hline \multirow[t]{2}{*}{ IAA } & 0.5 & $0.41 \pm 0.03 \mathrm{ab}$ & $0.19 \pm 0.02 \mathrm{ab}$ & $2.20 \pm 0.25 \mathrm{ac}$ & $0.12 \pm 0.01 \mathrm{ab}$ \\
\hline & 1.0 & $0.53 \pm 0.04 \mathrm{a}$ & $0.20 \pm 0.02 \mathrm{ab}$ & $2.77 \pm 0.32 \mathrm{ab}$ & $0.13 \pm 0.001 \mathrm{a}$ \\
\hline \multirow[t]{2}{*}{ NAA } & 0.5 & $0.01 \pm 0.001 \mathrm{e}^{* *}$ & $0.03 \pm 0.02 \mathrm{c}^{* *}$ & $0.40 \pm 0.04 \mathrm{c}$ & $0.0001 \pm 0.00 \mathrm{~d}^{* * *}$ \\
\hline & 1.0 & $0.02 \pm 0.001 \mathrm{e}^{* *}$ & $0.04 \pm 0.02 \mathrm{c}^{* *}$ & $1.31 \pm 0.73 \mathrm{ac}$ & $0.001 \pm 0.000 \mathrm{~d}^{* * *}$ \\
\hline \multirow[t]{2}{*}{ PIC } & 0.5 & $0.05 \pm 0.02 \mathrm{e}^{* * *}$ & $0.08 \pm 0.03 \mathrm{bc}^{* *}$ & $0.60 \pm 0.04 b c$ & $0.02 \pm 0.001 \mathrm{~d}^{* *}$ \\
\hline & 1.0 & $0.01 \pm 0.01 \mathrm{e}^{* *}$ & $0.03 \pm 0.01 \mathrm{c}^{* *}$ & $3.09 \pm 1.43 \mathrm{a}$ & $0.01 \pm 0.001 \mathrm{~d}^{* *}$ \\
\hline
\end{tabular}

${ }^{1}$ Means in columns \pm standard errors marked with the same letter do not differ significantly according to the HSD Tukey's test $(P \leq 0.05)$

* $B A$ 6-benzyladenine; IAA indole-3-acetic acid; KIN kinetin; NAA 1-naphthaleneacetic acid; PGR plant growth regulator; $P I C$ picloram; TDZ thidiazuron

** Concentration of pigments in callus

medium is much less effective (8.3-25.0\% rooting rate). BA also inhibited rhizogenesis in both cultivars tested. Interestingly, KIN had a positive influence on root development in the "White Gold" cultivar (62.5\% rooting rate). Similar results were reported with four cultivars of chrysanthemum (Kulus and Zalewska 2014). This phenomenon could be explained by the model proposed by Jones et al. (2010), in which cytokinins function as positive regulators of auxin biosynthesis.

Perhaps using a medium supplemented with both cytokinin and auxin could be beneficial to stimulate efficient root formation and shoot elongation of $L$. spectabilis, without the need for subsequent subcultures, as shown with Rauvolfia tetraphylla (Alatar and Faisal 2012).
Callogenesis Auxins promote cell growth expansion, initiation of cell division, and organization of meristems, which give rise to either unorganized tissue (callus) or defined organs (mainly roots) (Kou et al. 2013). In L. spectabilis, except for the naturally occurring IAA, auxins were predominant in callogenesis stimulation in both cultivars tested at low concentrations $\left(0.5 \mathrm{mg} \mathrm{L}^{-1}\right)$. Similar to Solanum tuberosum L. (Kawochar et al. 2017), NAA was essential for dynamic callus formation in bleeding heart. CKs were less effective for promoting this process, except for TDZ, which is in agreement with the studies by Thiruvengadam et al. (2010) and Zhang et al. (2011). The varied callus induction ability between plant growth regulators can be explained by different "sensitivity" of tissues to specific hormones. This 

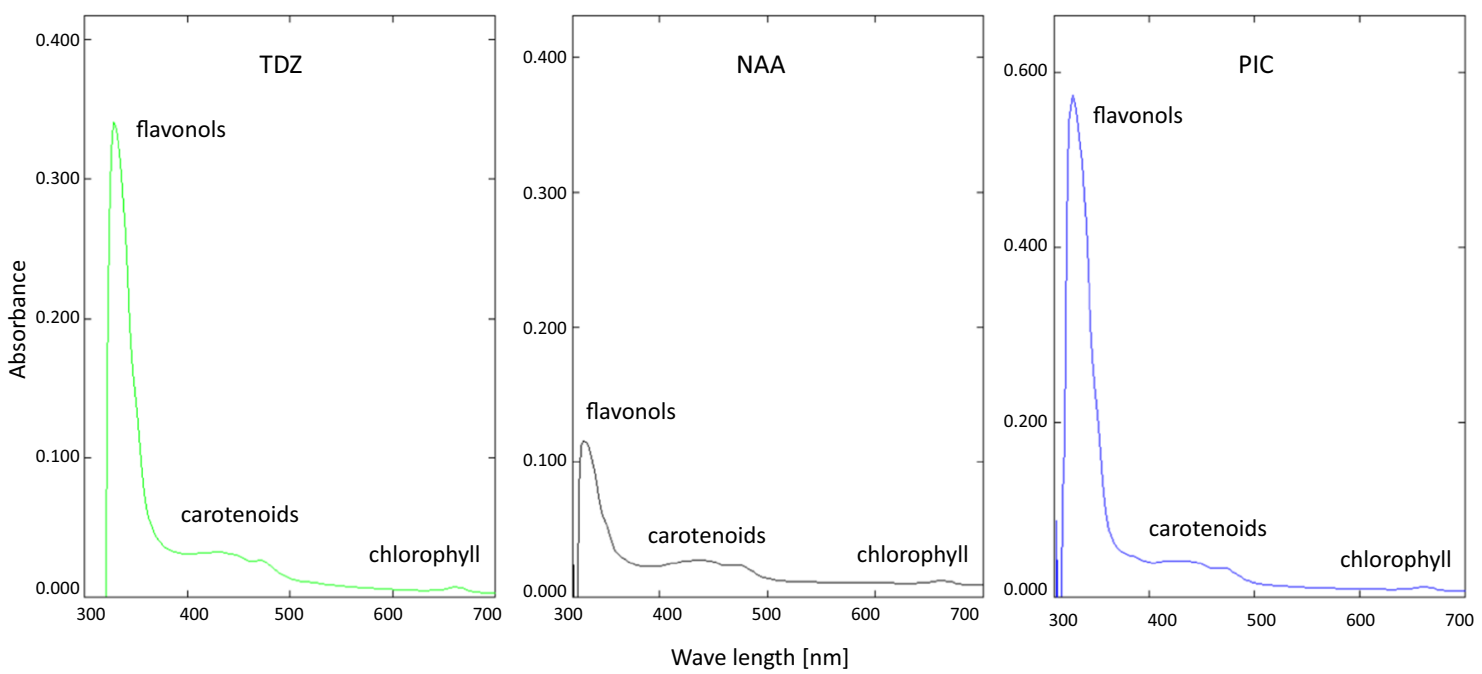

Figure 3. Absorbance curves of carotenoid, chlorophyll, and flavonol extracts in callus of Lamprocapnos spectabilis (L.) Fukuhara "White Gold" produced on the modified Murashige and Skoog medium

"sensitivity" and the effect of PGR change and depend on the developmental stage (degree of totipotency) and age of the tissue culture (Gaspar et al. 1996). Additional studies could focus on the induction of callus tissue with various morphology and structures in bleeding heart and the analysis of their chemical composition, as callus cultures can be a good source of pharmaceuticals (Mohammad et al. 2014).

Somatic embryogenesis in bleeding heart Apart from external agents, such as the culture medium composition or physical parameters in the growth room, the success or failure of the embryogenetic response is determined by several internal factors, such as age and type of explant, the level of endogenous PGRs, and also the genotype of the mother plant. Some species are considered "difficult" for inducing somatic embryogenesis, because the process can be repressed by the secreted in vitro metabolites, such as phenolic compounds, as reported in the Coffea genus (Nic-Can et al. 2015). Lema-Rumińska and Niedojadło (2010) obtained only 0.02 to 0.26 embryos per shoot explant in Copiapoa tenuissima Ritt $f$. monstruosa. It is also difficult to induce somatic embryogenesis in some woody plants (Guan et al. 2016). However, it is highly efficient with Citrullus colocynthis (L.) Schrad to generate true type clones (Ramakrishna and Shasthree 2016) and in large-scale and synchronic production of Anthurium andraeanum Lind. seedlings (Wang et al. 2019). These results suggest that Lamprocapnos spectabilis may be classified as a species with high embryogenetic potential, as somatic embryos were easily induced (up to 12 per 1-cm-long explant), in the medium supplemented with a low concentration (even $0.5 \mathrm{mg} \mathrm{L}^{-1}$ ) of PIC and in the "Gold Heart" cultivar with common and affordable NAA. In comparison, Constantin et al. (2015) used 20-mg L ${ }^{-1}$ NAA for embryogenic callus induction from leaf explants of Elaeis guineensis Jacq. var. Tenera. Auxins, usually 2,4-D, are the most supplemented with $0.5-\mathrm{mg} \mathrm{L}^{-1}$ thidiazuron (TDZ), 1-naphthaleneacetic acid (NAA), or picloram (PIC) after 8 wk. in culture.

broadly documented factor associated with the formation of embryogenic callus and pre-embryogenic masses (PEMs). The use of exogenous auxins induces the expression of various genes, which are primarily transcription factors (TFs), which modify the genetic program of the somatic cell and regulate the explants metabolism, which result in the activation of its embryogenic potential (Méndez-Hernández et al. 2019). Complementary with the present study, PIC ( 2.0 to $4.0 \mathrm{mg} \mathrm{L}^{-1}$ ) was also most effective for stimulating the proliferation of embryogenic callus in two carnation cultivars (Karami and Kordestani 2007). It is possible that this auxin might be a primary signal that initiates embryo formation in bleeding heart.

The somatic embryos obtained were morphologically similar to those described in numerous other plant species (Joshi and Kumar 2013). However, not all developmental stages typically observed in somatic embryogenesis could be found in all experimental combinations. For example, embryos at the heart stage were found only in the medium with $0.5-\mathrm{mg} \mathrm{L}^{-1}$ PIC. This may be related to the well-known issue of asynchronous development of embryos and the influence of various types and concentrations of PGRs on this phenomenon (Shen et al. 2018).

Effect of PGRs on the level of metabolites in plants Analysis of biochemical compounds is important, particularly for plants of medicinal use such as bleeding heart (Kalia et al. 2016). The biosynthetic activity of the plant can be affected by the type and concentration of PGRs used. Lucchesini et al. (2009) found that the level of valuable substances, such as caftaric, chlorogenic, and cichoric acids, in in vitro-grown Echinacea angustifolia DC. plants, was higher than in those grown in vivo, probably due to the presence of growth regulators in the culture medium. In the present study, the level of carotenoids and chlorophylls in bleeding heart was also affected by the medium composition. 
In addition to stimulating the proliferation of cells, cytokinins are also involved in the biosynthesis of chlorophyll and development of plastids. Consequently, it is often observed that somatic embryos formed on media supplemented only with auxins have a creamy/yellow color (Portillo et al. 2007), which is in agreement with this study. Cioć et al. (2019) found that the level of chlorophyll $a$ and carotenoids in the shoots of in vitro-produced Gerbera jamesonii Bolus increased with increasing concentrations of BA. Similarly, an exogenous application of CKs decreased chlorophyll degradation in different plant species grown in vivo (Dobránszki and Mendler-Drienyovszki 2014). In the present study however, shoots of the two cultivars of bleeding heart recovered on the IAA-supplemented medium, often had higher chlorophyll and carotenoid concentrations compared with those grown in media with BA or KIN. This may suggest that the chloroplasts of shoots grown in CK-supplemented media were dysfunctional, as their proper development is necessary for the normal response to CKs found by Kulaeva et al. (2002). Moreover, degradation of chlorophylls and carotenoids may be a symptom of premature senescence of the plants (Karatas et al. 2010). Therefore, the use of structural analogues of BA, such as 6-benzyal-adenine riboside (BAR) or meta-topolin (TOP), might be recommended for bleeding heart. Similar to these results, IAA had a stimulatory effect on the biosynthesis of chlorophylls and carotenoids in Wolffia arrhiza (L.) Wimm, unlike its analogues (NAA and phenylacetic acid (PAA)) (Czerpak et al. 2002). Those results confirmed that the effect of PGRs strongly depends on the biological material.

It is worth mentioning that in vitro cultivation of "Gold Heart" plants in a medium with $1.0-\mathrm{mg} \mathrm{L}^{-1} \mathrm{IAA}$ increased the concentration of the tested compounds, by approximately $50 \%$, compared with the control. Therefore, in vitro culture could be used for sustainable production of any metabolite of interest in bleeding heart. Those results could be important for the pharmaceutical industry for the overproduction of constituents with medicinal use and should be explored in the future.

\section{Conclusions}

The present study demonstrated that the morphogenetic response of nodal explants of bleeding heart is cultivar- and PGR-specific. The addition of $0.5-\mathrm{mg} \mathrm{L}^{-1} \mathrm{KIN}$ to the modified MS medium improved the biometrical parameters of axillary shoots in L. spectabilis "Gold Heart" (their number, length, and number of leaves). This effect, however, is not observed with "White Gold." NAA and IAA are preferable for rhizogenesis induction and root elongation, respectively, in both cultivars tested. It was also quite easy to induce indirect somatic embryogenesis in both cultivars studied in the presence of 0.5 to $1.0-\mathrm{mg} \mathrm{L}^{-1} \mathrm{PIC}$ or NAA (in "Gold Heart" only). Composition of the culture medium significantly affected the synthesis of primary and secondary metabolites in the tissues of bleeding heart. The auxin IAA, at $1.0 \mathrm{mg} \mathrm{L}^{-1}$, increased the production of chlorophyll $a$ and carotenoids in the shoots by $50 \%$ compared with the PGR-free control. These results serve as a first step to optimize culture media for a variety of purposes, such as for in vitro propagation, conservation, metabolite extraction, or plant breeding.

Acknowledgments The author wishes to acknowledge Mr. Cihat Değirmenci for technical support in performing this research.

\section{Compliance with ethical standards}

Conflict of interest The author declares that there are no conflicts of interest.

Open Access This article is licensed under a Creative Commons Attribution 4.0 International License, which permits use, sharing, adaptation, distribution and reproduction in any medium or format, as long as you give appropriate credit to the original author(s) and the source, provide a link to the Creative Commons licence, and indicate if changes were made. The images or other third party material in this article are included in the article's Creative Commons licence, unless indicated otherwise in a credit line to the material. If material is not included in the article's Creative Commons licence and your intended use is not permitted by statutory regulation or exceeds the permitted use, you will need to obtain permission directly from the copyright holder. To view a copy of this licence, visit http://creativecommons.org/licenses/by/4.0/.

\section{References}

Alatar A, Faisal M (2012) Encapsulation of Rauvolfia tetraphylla microshoots as artificial seeds and evaluation of genetic fidelity using RAPD and ISSR markers. J Med Plants Res 6:1367-1374. https://doi.org/10.5897/JMPR11.1632

Cioć M, Kalisz A, Żupnik M, Pawłowska B (2019) Different LED light intensities and 6-benzyladenine concentrations in relation to shoot development, leaf architecture, and photosynthetic pigments of Gerbera jamesonii bolus in vitro. Agronomy 9:358. https://doi. org/10.3390/agronomy9070358www.mdpi.com/journal/agronomy

Constantin M, Nchu WA, Godswill N, Wiendi NMA, Wachjar A, Frank NEG (2015) Induction of oil palm (Elaeis guineensis Jacq. Var. Tenera) callogenesis and somatic embryogenesis from young leaf explants. $\mathrm{J}$ Appl Biol Biotechnol 3:4-10. https://doi.org/10.7324/JABB.2015.3402

Czerpak R, Dobrzyń P, Krotke A, Kicińska E (2002) The effect of auxins and salicylic acid on chlorophyll and carotenoid contents in Wolffia arrhiza (L.) Wimm. (Lemnaceae) growing on media of various trophicities. Pol J Environ Stud 11:231-235

Dobránszki J, Mendler-Drienyovszki N (2014) Cytokinin-induced changes in the chlorophyll content and fluorescence of in vitro apple leaves. J Plant Physiol 171:1472-1478. https://doi.org/10.1016/j. jplph.2014.06.015

Gaspar T, Kevers C, Penel C, Greppin H, Reid DM, Thorpeet TA (1996) Plant hormones and plant growth regulators in plant tissue culture. In Vitro Cell Dev Biol-Plant 32:272. https://doi.org/10.1007/ BF02822700

Guan Y, Li SG, Fan XF, Su ZH (2016) Application of somatic embryogenesis in woody plants. Front Plant Sci 7:938. https://doi.org/10. 3389/fpls.2016.00938

Hodges L (2012) Bleeding heart: a review for growers. Hort Technol 22(4):517-522 
Huang W, Ratkowsky DA, Hui C, Wang P, Su J, Shi P (2019) Leaf fresh weight versus dry weight: which is better for describing the scaling relationship between leaf biomass and leaf area for broad-leaved plants? Forests 10:256. https://doi.org/10.3390/f10030256

Iwasa K, Kim C-W (1997) Biotransformations of protoberberines in cell cultures of Dicentra spectabilis. Phytochem 46:1359-1363

Jones B, Andersson Gunneråsb S, Peterssonb SV, Tarkowski P, Grahamc N, Mayc S, Dolezalb K, Sandberga G, Ljung K (2010) Cytokinin regulation of auxin synthesis in Arabidopsis involves a homeostatic feedback loop regulated via auxin and cytokinin signal transduction. Plant Cell 22:2956-2969

Joshi R, Kumar P (2013) Regulation of somatic embryogenesis in crops: a review. Agric Rev 34:1-20

Kalia R, Katnoria JK, Nagpal AK (2016) Antitumor activity of aqueous leaf extracts of Chrysanthemum morifolium R. using potato disc tumor assay. J Pharm Sci Res 8:1262-1265

Karami O, Kordestani GK (2007) Proliferation, shoot organogensis and somatic embryogenesis in embryogenic callus of carnation. J Fruit Ornam Plant Res 15:167-175

Karatas I, Ozturk L, Ersahin Y, Okatan Y (2010) Effects of auxin on photosynthetic pigments and some enzyme activities during darkinduced senescence of tropaeolum leaves. Pak J Bot 42:1881-1888

Kawochar A, Ahmed NU, Hossain I, Ferdois J (2017) Role of explants and NAA on callus induction of potato (Solanum tuberosum). Am J Life Sci 5:140-144. https://doi.org/10.11648/j.ajls.20170505.14

Kou Y, Ma G, da Silva JAT, Liu N (2013) Callus induction and shoot organogenesis from anther cultures of Curcuma attenuata wall. Plant Cell Tiss Org Cult 112:1-7. https://doi.org/10.1007/s11240012-0205-y

Kulaeva ON, Burkhanova EA, Karavaiko NN, Selivankina SY, Porfirova SA, Maslova GG, Zemlyachenkoa YV, Börner T (2002) Chloroplasts affect the leaf response to cytokinin. J Plant Physiol 159:1309-1316. https://doi.org/10.1078/0176-1617-00761

Kulus D (2015) Selected aspects of ornamental plants micropropagation in Poland and worldwide. Life Sci 4:10-25. https://doi.org/10. 13140/RG.2.1.5086.8082

Kulus D, Zalewska M (2014) In vitro plant recovery from alginate encapsulated Chrysanthemum $\times$ grandiflorum/Ramat./Kitam. Shoot tips. Prop Ornam Plants 14:3-12

Lee KP, Lee DW (2003) (2003) somatic embryogenesis and plant regeneration from seeds of wild Dicentra spectabilis (L.) Lem. Plant Cell Rep 22:105-109. https://doi.org/10.1007/s00299-003-0642-5

Lee K-S, Sim O-K, Shin J-S, Choi Y-E, Kim E-Y (2004) Mass propagation of Dicentra spectabilis L. Lemaire through in vitro suspension culture. J Plant Biotechnol 31:121-126

Lema-Rumińska J, Niedojadło J (2010) Induction of somatic embryogenesis in cacti Copiapoa tenuissima Ritt forma monstruosa. Acta Biol Cracov Ser Bot 52:1-6

Lichtenthaler HK (1987) Chlorophylls and carotenoids: pigments of photosynthetic biomembranes. Met Enzymol 148:350-382

Lichtenthaler HK, Buschmann C (2001) Chlorophylls and carotenoids: measurement and characterization by UV-VIS spectroscopy. Curr Prot Food Analyt Chem 1:F4.3.1-F4.3.8. https://doi.org/10.1002/ 0471142913.faf0403s01

Lidén M, Fukuhara T, Rylander J, Oxelman B (1997) Phylogeny and classification of Fumariaceae, with emphasis on Dicentra s. 1., based on the plastid gene rpsl6 intron. Plant Syst Evol 206:411-420

Lucchesini M, Bertoli A, Mensuali-Sodi A, Pistelli L (2009) Establishment of in vitro tissue cultures from Echinacea angustifolia D.C. adult plants for the production of phytochemical compounds. Sci Hortic 122:484-490. https://doi.org/10.1016/j.scienta.2009.06.011

McNulty J, Poloczek J, Larichev V, Werstiuk NH, Griffin C, Pandey S (2007) Discovery of the apoptosis-inducing activity and high accumulation of the butenolides, menisdaurilide and aquilegiolide in Dicentra spectabilis. Planta Med 73:1543-1547. https://doi.org/10. 1055/s-2007-990264
Méndez-Hernández HA, Ledezma-Rodríguez M, Avilez-Montalvo RN, Juárez-Gómez YL, Skeete A, Avilez-Montalvo J, De-la-Peña C, Loyola-Vargas VM (2019) Signaling overview of plant somatic embryogenesis. Front Plant Sci 10:77. https://doi.org/10.3389/fpls.2019.00077

Miler N, Kulus D, Woźny A, Rymarz D, Hajzer M, Wierzbowski K, Nelke R, Szeffs L (2019) Application of wide-spectrum light-emitting diodes in micropropagation of popular ornamental plant species: a study on plant quality and cost reduction. In Vitro Cell Dev Biol-Plant 55:99-108. https://doi.org/10.1007/s11627-018-9939-5

Mohammad S, Alam P, Ahmad MM, Ali A, Ahmad J, Abdin MZ (2014) Impact of plant growth regulators (PGRs) on callogenesis and artemisinin content in Artemisia аппиа L. plants. Indian J Biotechnol 13:26-33

Murashige T, Skoog F (1962) A revised medium for rapid growth and bio assays with tobacco tissue cultures. Physiol Plant 15:473-497. https://doi.org/10.1111/j.1399-3054.1962.tb08052.x

Nic-Can GI, Galaz-Ávalos RM, De-la-Peña C, Alcazar-Magaña A, Wrobel K, Loyola-Vargas VM (2015) Somatic embryogenesis: identified factors that lead to embryogenic repression. A case of species of the same genus. PLoS One 10(6):e0126414. https://doi. org/10.1371/journal.pone. 0126414

Overvoorde P, Fukaki H, Beeckman T (2010) Auxin control of root development. Cold Spring Harb Perspect Biol 2(6):a001537. https://doi.org/10.1101/cshperspect.a001537

Pahnekolayi MD, Samiei L, Tehranifar A, Shoor M (2015) Micropropagation of Rosa canina through axillary shoot proliferation. J Plant Mol Breed 3:61-71

Portillo L, Santacruz-Ruvaleaba R, Gutierez-Mora A, Rodriguez-Garay B (2007) Somatic embryogenesis in Agave tequilana weber cultivar Azul. In Vitro Cell Dev Biol-Plant 43:569-575. https://doi.org/10. 1007/s11627-007-9046-5

Ramakrishna D, Shasthree T (2016) High efficient somatic embryogenesis development from leaf cultures of Citrullus colocynthis (L.) Schrad for generating true type clones. Physiol Mol Biol Plants 22:279-285. https://doi.org/10.1007/s12298-016-0357-z

Roberts CM, Serek M, Andersen AS (1995) Supplemental irradiance and STS improve the display life of Dicentra species forced as flowering potted plants. Sci Hortic 62:121-128. https://doi.org/10.1016/03044238(95)00774-N

Shen HJ, Chen JT, Chung HH, Chang WC (2018) Plant regeneration via direct somatic embryogenesis from leaf explants of Tolumnia Louise Elmore 'Elsa'. Bot Stud 59:4. https://doi.org/10.1186/s40529-0180220-3

Simon S, Petrášek P (2011) Why plants need more than one type of auxin. Plant Sci 180:454-460. https://doi.org/10.1016/j.plantsci.2010.12.007

Thiruvengadam M, Rekha K, Yang C-H, Jayabalan N, Chung I-M (2010) High-frequency shoot regeneration from leaf explants through organogenesis in bitter melon (Momordica charantia L.). Plant Biotechnol Rep 4:321-328. https://doi.org/10.1007/s11816-010-0151-2

Tymoszuk A, Antkowiak M (2018) In vitro adventitious organogenesis in Ajania pacifica (Nakai) Bremer et Humphries. BioTechnologia 99: 335-343. https://doi.org/10.5114/bta.2018.79964

Wang G, Xu C, Yan S, Xu B (2019) An efficient somatic embryo liquid culture system for potential use in large-scale and synchronic production of Anthurium andraeanum seedlings. Front Plant Sci 10:29. https://doi.org/10.3389/fpls.2019.00029

We SL, Alderson PG, Yap WSP (2015) Establishment of plantlet regeneration system from nodal, internodal and leaf explants of Sauropus androgynus (sweet shoot). Asian J Biotechnol 7:46-59. https://doi. org/10.3923/ajbkr.2015.46.59

Zhang S, Liu N, Sheng A, Ma G, Wu G (2011) In vitro plant regeneration from organogenic callus of Curcuma kwangsiensis Lindl. (Zingiberaceae). Plant Growth Regul 64:141-145. https://doi.org/ 10.1007/s10725-010-9548-8 